\title{
Aleksandra Lubczyńska
}

(Jan Kochanowski University in Kielce, Poland)

https://orcid.org/0000-0001-8834-6142

E-mail: aleksandra.lubczynska@ujk.edu.pl

\section{Narodowa Demokracja w procesie kształtowania świadomości i tożsamości narodowej Polaków przed I wojną światową w świetle publicystyki „Przeglądu Narodowego” (1908-1914)}

\section{National Democracy Shaping Pre-War Polish Consciousness and Identity Through the Journal "Przegląd Narodowy" (1908-1914)}

\section{ABSTRACT}

National Democracy belonged to the largest and most serious - next to socialists, conservatives and people's movement - political forces of the turn of the 19th and 20th centuries. In the period before World War I, it had a lot of social support, which stemmed from the fact

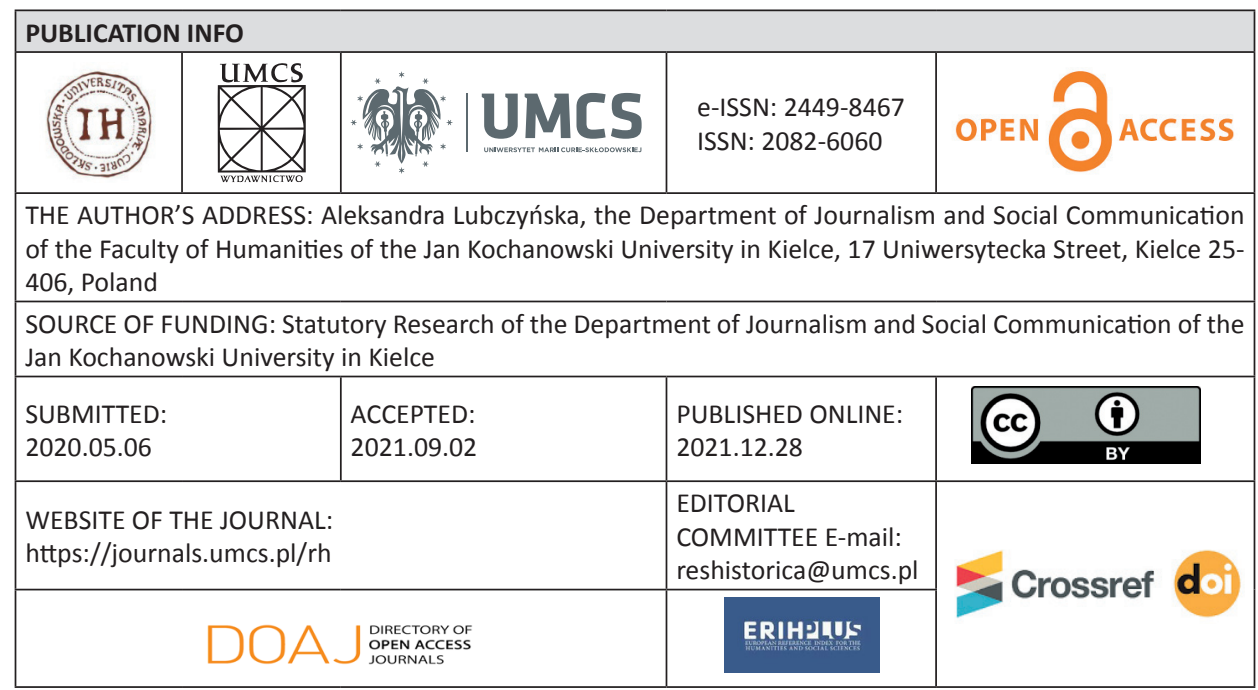


that one of the basic elements of her identity were independence slogans and an educational program. It was also one of those political forces that appreciated the role of the press in promoting its own ideology. National Democracy is considered the creator of one of the most opinion-forming press systems before 1939, with a large number of titles intended for a diverse audience, and a network of distribution of this press. National Democracy used the press to transmit political thought and to achieve its current political aims.

The subject of the discussion in this article is the problem of shaping the national consciousness and national identity of Poles, undertaken in „Przegląd Narodowy” („National Review"), published in Warsaw in 1908-1914 edited by Zygmunt Balicki.

Key words: National Democracy, press, „Przegląd Narodowy” („National Review”), political journalism, national consciousness, national identity

\section{STRESZCZENIE}

Narodowa Demokracja należała do największych i najpoważniejszych - obok socjalistów, konserwatystów i ruchu ludowego - sił politycznych przełomu XIX i XX w. W okresie przed I wojną światową miała duże poparcie społeczne, które wynikało m.in. z faktu, że jednym z podstawowych elementów jej tożsamości były hasła niepodległościowe oraz program wychowawczy. Należała także do tych sił politycznych, które doceniły rolę prasy w propagowaniu własnej ideologii. Uznaje się, że stworzyła jeden z najbardziej opiniotwórczych systemów prasowych przed 1939 r., wyróżniający się dużą liczbą tytułów przeznaczonych dla różnorodnego odbiorcy oraz siecią kolportażu i dystrybucji tej prasy. Narodowa Demokracja wykorzystywała prasę do transmisji myśli politycznej oraz do osiągania bieżących celów politycznych.

Przedmiotem rozważań w niniejszym artykule jest problem kształtowania świadomości i tożsamości narodowej Polaków, podejmowany na łamach organu prasowego ruchu - „Przeglądu Narodowego", ukazującego się w Warszawie w latach 1908-1914 pod redakcją Zygmunta Balickiego.

Słowa kluczowe: Narodowa Demokracja, prasa, „Przegląd Narodowy”, publicystyka polityczna, świadomość narodowa, tożsamość narodowa

Narodowa Demokracja należała do największych i najpoważniejszych - obok socjalistów, ruchu ludowego i konserwatystów - sił politycznych przełomu XIX i XX w. W okresie przed I wojną światową miała duże poparcie społeczne, które wynikało m.in. z faktu, że jednym z podstawowych elementów jej tożsamości były hasła niepodległościowe oraz program wychowawczy. Szczególnie ten ostatni można uznać za osiągnięcie wyjątkowe. Skierowany był do szerokich warstw społeczeństwa i budził w nim poczucie polskości oraz świadomość narodowa; dając nadzieję na wolność - zachęcał do podejmowania wysiłków na wielu polach politycznej, społecznej i kulturalnej działalności ${ }^{1}$.

1 Por. E. Paruzel, Ideał wychowawczy Narodowej Demokracji i próby jego realizacji na przełomie XIX i XX wieku, Toruń 1993. 
Dysponując dość licznymi i różnorodnymi środkami oddziaływania na społeczeństwo, Narodowa Demokracja miała znaczne szanse, by kształtować wyobrażenia znacznej części Polaków². Podstawowymi środkami komunikowania były przede wszystkim książki, broszury oraz prasa. Zwłaszcza ta ostatnia odegrała ogromną rolę w ideowopolitycznej ekspansji ruchu. Jego liderzy doceniali znaczenie informacji i w celu jej dystrybucji inicjowali i rozwijali tytuły prasowe o rozmaitej częstotliwości: od dzienników po miesięczniki. Jak wykazała badaczka tej prasy Urszula Jakubowska, w dobie zaborów w posiadaniu Narodowej Demokracji znajdowało się ponad 120 tytułów pism o różnej częstotliwości wydawania i skierowanych do różnych odbiorców. Przegląd adresatów tych pism wskazuje, że systematycznie wprowadzano w obieg nowe tytuły, biorące pod uwagę specyficzne potrzeby i oczekiwania bardzo różnorodnego odbiorcy $^{3}$. Aneta Dawidowicz z kolei zauważyła, że Narodowa Demokracja od zawsze traktowała prasę utylitarnie, jako jedną z form upowszechniania myśli politycznej, a zarazem jako narzędzie wspomagające osiąganie doraźnych celów politycznych. Ponadto redakcje wielu czasopism stanowiły prężne ośrodki życia politycznego, kulturalnego i narodowego, skupiające liderów i działaczy obozu narodowodemokratycznego oraz jego sympatyków. Endecja była obozem politycznym, który przed 1939 r. stworzył jeden z najbardziej opiniotwórczych systemów prasowych ${ }^{4}$.

„Przegląd Narodowy. Miesięcznik poświęcony zagadnieniom życia narodowego w zakresie politycznym, naukowym, społecznym, literackim i artystycznym" wydawany był w Warszawie w latach 1908-1914 i miał charakter pisma programowego ${ }^{5}$. Uchodził za kontynuatora wychodzącego tam w latach 1895-1905 „Przeglądu Wszechpolskiego”, który realizował podobne zadania $\mathrm{w}$ zakresie precyzowania i propagowania ideologii nacjonalistycznej oraz wytyczania głównych koncepcji politycznych ${ }^{6}$.

2 R. Wapiński, Narodowa Demokracja 1893-1939. Ze studiów nad dziejami myśli nacjonalistycznej, Wrocław 1980, s. 11.

3 U. Jakubowska, Prasa Narodowej Demokracji w dobie zaborów, Warszawa-Łódź 1988, s. 11.

4 A. Dawidowicz, Rola prasy w rozwoju Narodowej Demokracji (1893-1939), w: Polityka i politycy w prasie XX i XXI wieku, red. M. Dajnowicz, A. Miodowski, Białystok 2016, s. 231.

5 O "Przeglądzie Narodowym" pisały już: U. Jakubowska, "Przegląd Narodowy" 1908-1914, „Kwartalnik Historii Prasy Polskiej” 1984, 23, 3, s. 99-118; A. Dawidowicz "Przegląd Narodowy" 1908-1914; 1919-1921, w: Prasa Narodowej Demokracji (1886-1939), red. A. Dawidowicz, E. Maj, Lublin 2010, s. 49-65; A. Lubczyńska, "Ateneum Polskie” 1908. "Przegląd Narodowy" 1908-1914. Adnotowana bibliografia zawartości, Kielce 2017.

6 B. O. [Z. Balicki], Z teorii polityki narodowej, "Przegląd Narodowy" [dalej: "PN"] 1909, 2, 10, s. 464. Por. R. Wapiński, "Przeglad Wszechpolski" (1895-1905, 1922-1926), w: Na warsztatach historyków polskiej myśli politycznej. Polska myśl polityczna XIX i XX wieku, red. H. Zieliński, Wrocław 1980, s. 79-93. 
Powstał z inicjatywy Zygmunta Balickiego - jednego z najwybitniejszych działaczy i teoretyków polskiego nacjonalizmu. Jego redakcję, oprócz Balickiego, tworzyli znani publicyści związani z obozem narodowodemokratycznym: Wacław Dunin, Mieczysław Niklewicz oraz Jerzy Gościcki Miesięcznik reprezentował idee Narodowej Demokracji, realizował program Stronnictwa Demokratyczno-Narodowego i stanowił jeden z głównych teoretycznych organów ruchu narodowodemokratycznego. Jego zadania miały polegać na rozwijaniu i rozszerzaniu myśli teoretycznej, pogłębianiu założeń programowych i rozbudzaniu ruchu umysłowego w tym kierunku. Motywację do prowadzenia pisma o takim charakterze czerpano z przeświadczenia, że od dłuższego czasu zbyt dużo uwagi także $\mathrm{w}$ prasie - kierownictwo ruchu poświęcało sprawom bieżącym, związanym z aktualną polityką, spychając na margines głębszą refleksję teoretyczną. Jak jednak ustaliła Jakubowska, powstanie „Przeglądu Narodowego" w takim kształcie związane było ściśle z faktem, że ok. 1907 r. w dziejach Narodowej Demokracji nastąpił zwrot kierunku politycznego z przyjęciem przezeń orientacji na Rosję. W takich okolicznościach pismo miało włączyć się do dyskusji i uzasadniania nowych założeń, zwłaszcza że nawet w samym obozie nie zawsze znajdowały one akceptację ${ }^{8}$.

Choć w teorii zasięg pisma nie był ograniczony kordonami granicznymi, to w praktyce, na skutek różnych okoliczności, które zdecydowały o doborze współpracowników, dominowały w nim poglądy i myśl narodowych demokratów zaboru rosyjskiego. Według Jakubowskiej takie zawężenie perspektywy stanowiło problem dla redakcji, ale nawet będąc świadomym, kierownictwo „Przeglądu” nie umiało sobie z nim poradzić9. Ogólnie jednak rzecz ujmując, poglądy wyrażane w miesięczniku, $\mathrm{z}$ racji roli, którą pełnił, odzwierciedlały stanowisko endecji wobec różnorodnych zjawisk i problemów życia politycznego. Eksponowano głównie zagadnienia ogólne, dotyczące wspólnoty narodowej, obowiązku narodowego, wychowania narodowego ${ }^{10}$.

Charakter treści publikowanych w "Przeglądzie Narodowym” sprawiał, że znajdował on odbiorców pośród czytelników rekrutujących się z kręgów elit intelektualnych, zainteresowanych przede wszystkim sprawami politycznymi, chcących poszerzyć swoją wiedzę $\mathrm{w}$ tym zakresie. Zapewniały to nie tylko różnorodna problematyka artykułów, ale także ich wysoki poziom merytoryczny. Mimo wyraźnego charakteru poli-

\footnotetext{
U. Jakubowska, "Przegląd, s. 99; A. Dawidowicz, "Przeglad, s. 49-50.

U. Jakubowska, „Przegląd, s. 99-101.

Ibidem, s. 107.

10 A. Dawidowicz, „Przeglad, s. 65.
} 
tycznego pisma, jego łamy udostępniano także przedstawicielom nauki, świata literackiego i artystycznego, którzy zamieszczali nieraz obszerne, erudycyjne teksty o sztuce i literaturze, a także, choć w mniejszym stopniu - utwory poetyckie i fragmenty prozy ${ }^{11}$. Między innymi właśnie ta różnorodność problematyki artykułów oraz ich wysoki poziom merytoryczny sprawiły, że miesięcznik zajmował ważne miejsce w systemie prasowym Narodowej Demokracji i odegrał dużą rolę w procesie kształtowania polskiej i narodowej myśli politycznej.

Celem niniejszego artykułu jest analiza tekstów opublikowanych na łamach „Przeglądu Narodowego”. Jednakże z uwagi na ogromną rozpiętość podejmowanych tam temató ${ }^{12}$, skoncentrowałam się na jednym, wybranym problemie: na treściach, których zadaniem było kształtowanie świadomości i tożsamości narodowej społeczeństwa. To ostatnie było bowiem jednym z najważniejszych działań, podejmowanych na łamach endeckich pism i wynikało z przeświadczenia ideologów ruchu, że kluczem do suwerenności polityczno-ekonomicznej Polaków jest aktywizacja

11 Ibidem, s. 51-52.

12 O tym, jaki potencjał tkwi w "Przeglądzie Narodowym” świadczą chociażby następujące artykuły: M. Białokur, Stosunki polsko-ukraińskie w Galicji na łamach "Przeglądu Narodowego" (1908-1914), „Rocznik Historii Prasy Polskiej” 2002, 2, s. 103-122 - w artykule autor wyzyskał publicystykę „Przeglądu Narodowego" dla odtworzenia klimatu i atmosfery, w jakich kształtował się obraz relacji polsko-ukraińskich na terenie Galicji; D. LitwinekLewandowska, Elity polityczne Galicji w opinii "Przegladu Narodowego" w latach 1908-1914, „Annales Universitatis Mariae Curie-Skłodowska. Sectio K, Politologia” 2004, 11, s. 211-222 - dla autorki zawartość pisma stanowiła podstawę do rozważań na temat problematyki związanej ze stosunkami pomiędzy galicyjskimi ugrupowaniami politycznymi, tj. konserwatystami, Narodową Demokracją i partiami ludowymi; J.M. Majchrowski, Kościót i katolicyzm na łamach "Przegladu Narodowego", "Zeszyty Naukowe Uniwersytetu Jagiellońskiego. Prace Historycznoliterackie" 1986, 55, s. 115-128 oraz I. Zaleska, Kościót, religia, duchowieństwo w świetle "Przegladu Wszechpolskiego" oraz "Przegladu Narodowego" w latach 1895-1914, "Historia i Polityka” 2007, 6, s. 47-61 - w tym przypadku pismo było źródłem do badań nad rola, jaką Narodowa Demokracja przypisywała Kościołowi katolickiemu - jedynej, trójzaborowej polskiej instytucji o charakterze publicznym, która miała prawo do posługiwania się językiem polskim w ramach swojej działalności wśród wiernych, nad rolą religii katolickiej - stanowiącej jeden z najważniejszych czynników narodowej tożsamości społeczeństwa polskiego - słowem - nad religią jako przedmiotem polityki; K. Śmiechowski, Endeckie postrzeganie miasta. Ewolucja tematyki miejskiej na tamach "Przegladu Wszechpolskiego" i "Przegladu Narodowego", "Studia Podlaskie" 2018, 26, s. 7-26 - publicystyka omawianego pisma była podstawą do opracowania tekstu na temat stosunku endecji do miejskości i kwestii miejskiej i scharakteryzowania, w jaki sposób jej ideolodzy kreślili pozycję miejskich grup społecznych w światopoglądzie polskiego ruchu narodowego; A. Dawidowicz, Droga do niepodległości Polski w myśli politycznej Narodowej Demokracji, „Myśl Ludowa” 2013, 5, s. 75-88 - tutaj teksty z „Przeglądu Narodowego” były dla autorki cennym źródłem do badań nad wizją niepodległości Polski, przekazywaną $\mathrm{w}$ dokumentach programowych oraz w publicystyce endeckiej. 
wszystkich warstw społecznych narodu, także tych, które dotychczas nie miały prawa głosu, a ze względu na swą liczebność i tkwiący w nich potencjał - zasługiwały na to ${ }^{13}$.

Zagadnienie roli Narodowej Demokracji w kształtowaniu świadomości i tożsamości narodowej pojawiło się w refleksjach historyczno-politologicznych już wielokrotnie ${ }^{14}$. Istotne miejsce $w$ dorobku badawczym zajmują liczne opracowania, w których wskazywano na różnorodne czynniki (tradycję, historię, wychowanie, religię), mające największy wpływ na te procesy. Omówienie stanu badań nad różnymi aspektami dziejów i myśli politycznej endecji oraz obszerną bibliografię zawierają artykuły Anety Dawidowicz ${ }^{15}$ i Ewy Maj ${ }^{16}$. Ważną pozycją - w odniesieniu do zagadnień zasygnalizowanych w tytule niniejszego artykułu - jest wydana w 2012 r. monografia Katarzyny Wrzesińskiej ${ }^{17}$. Autorka omówiła w niej politykę kulturową Narodowej Demokracji na przełomie XIX i XX w. Wykorzystując publicystykę i wydawnictwa programowe narodowych demokratów odniosła się do takich pojęć jak naród, nacjonalizm, patriotyzm. Przedstawiła dzieje myśli narodowodemokratycznej w sposób pokazujący zarówno jej mocne zakorzenienie w spuściźnie zachodnioeuropejskiej, jak i rodzimej, oraz ukazała ową myśl jako siłę jednoczącą naród pomimo granic rozbiorowych. Zwróciła uwagę na endecką koncepcję narodu, według której miał on się stać uniwersalną wartością spajającą społeczeństwo. Akcentowała wartości kulturowe jako przesłanki do odbudowy państwa. Przypomniała, że narodowcy uważali nacjonalizm za wypływający z patriotyzmu kolejny etap postępu $\mathrm{w}$ dziejach ludzkości, prowadzący do umocnienia indywidualności każdego z narodów (państw). Zaakcentowała, że nowoczesność i oryginalność endeckiego ujęcia narodu i nacjo-

13 Program Stronnictwa Demokratyczno-Narodowego w zaborze rosyjskim, „Przegląd Wszechpolski" 1897, 11, s. 3.

14 Np.: W. Konieczny, Formowanie i umacnianie świadomości narodowej jako elementarne zadanie polityczne Narodowej Demokracji na przełomie XIX i XX wieku, "Studia Historyczne” 1989, 4, s. 545-559; R. Wapiński, Polska i małe ojczyzny Polaków. Z dziejów ksztattowania się świadomości narodowej w XIX i XX wieku po wybuch II wojny światowej, Wrocław 1994; K. Kawalec, Narodowa Demokracja wobec przemian świadomości narodowej Polaków w latach 1918-1939, w: Wrocławskie Studia z Historii Najnowszej, red. W. Wrzesiński, t. 6, Wrocław 1998, s. 21-36; K. Jakubiak, Idea wychowania obywatelskiego w polskiej myśli pedagogicznej przełomu XIX i XX wieku oraz Drugiej Rzeczypospolitej, w: Wychowanie a polityka. Między wychowaniem narodowym a państwowym, red. W. Wojdyło, Torun 1999, s. 91-99.

15 A. Dawidowicz, Stan badań nad dziejami i myśla polityczna Narodowej Demokracji, „Atheneaum" 2012, 33, s. 235-250.

16 E. Maj, O badaniu myśli politycznej Narodowej Demokracji do roku 1939. Wybrane zagadnienia, „Myśl Polityczna” 2020, 1, s. 31-60.

17 K. Wrzesińska, Kultura i cywilizacja w myśli Narodowej Demokracji (1893-1918). Między idea wychowania a polityka, Warszawa 2012. 
nalizmu polegała na niespotykanej dotąd powszechności świadomego udziału wszystkich warstw społecznych w budowaniu narodowego bytu. Ponadto autorka omówiła sprawy edukacji w szerokim kontekście myśli nacjonalistycznej oraz wpływ tej idei na polską inteligencję.

W poniższym artykule natomiast starano się przedstawić problematykę tożsamości narodowej tak, jak warszawskiej opinii publicznej przekazywało ją środowisko narodowe za pośrednictwem publicystyki „Przeglądu Narodowego", co, być może, przyczyni się do uzupełnienia wiedzy na temat form komunikowania politycznego Narodowej Demokracji.

Wśród artykułów podejmujących tę tematykę można wyróżnić trzy zasadnicze grupy, a tym samym trzy aspekty zagadnień. Pierwsza grupa to artykuły, których motywem były dzieje kształtowania się świadomości i tożsamości narodowej Polaków. Punktem wyjścia do ich omówienia jest świadomość, że narodowi demokraci prezentowali charakterystyczny stosunek do zagadnienia narodu. Badania historyków, socjologów i politologów potwierdziły tezę, że w okresie poprzedzającym wybuch I wojny światowej animatorzy ruchu pozostawali w kręgu narodu jako kategorii historycznej, rozumiejąc go jako wspólnotę ukształtowaną przez historię ${ }^{18}$. Tak pojmowany uznawali za wartość, której winny być podporządkowane inne wartości, takie jak państwo, polityka i gospodarka. Według programu endecji wartości etyczne jednostki winny być podporządkowane interesom narodu, a jego rozwój i dobro miały stanowić główne zadanie wszelkich działań politycznych, społecznych i gospodarczych. Nadrzęd-

18 Por. W. Wojdyło, Rola tradycji w kształtowaniu idei narodu jako kategorii historycznej w myśli politycznej obozu narodowodemokratycznego, w: Marzyciele i realiści. O roli tradycji w polskiej myśli politycznej od upadku powstania styczniowego do XXI wieku, red. T. Sikorski, A. Wątor, Szczecin 2009, s. 185-189. W opinii narodowych demokratów naród był wytwarzany przez wspólne losy dziejowe, wszystkie jego wady i zalety, pierwiastki świadomości społecznej i politycznej, tradycję narodowa, duchowe i materialne pamiątki historyczne oraz zabytki kultury przodków. Odwoływanie się do własnej, narodowej przeszłości determinowało rozwój poczucia więzi międzypokoleniowej. Zob. także m.in.: R. Wapiński, Idea narodu w myśli społecznej i politycznej endecji przed rokiem 1918, w: Idee i koncepcje narodu w polskiej myśli politycznej czasów porozbiorowych, red. J. Gaćkowski, A. Walicki, Warszawa 1977, s. 220-224; A. Walicki, Naród i terytorium. Obszar narodowy w myśli politycznej Romana Dmowskiego, „Dziś” 2002, 7, s. 22-41; T. Kizwalter, O nowoczesności narodu. Przypadek polski, Warszawa 1999 (szczeg. s. 276-324); A. Dawidowicz, Problematyka narodowa w myśli politycznej Zygmunta Balickiego, „Polityka i Społeczeństwo” 2004, 1, s. 132 152. W tej ostatniej pracy autorka pisze o trudnościach w badaniach nad koncepcją narodu w myśli politycznej Narodowej Demokracji z uwagi na fakt, że w pismach i publicystyce, szczególnie w okresie przed odzyskaniem niepodległości, nie stanowiła ona zwartej konstrukcji ideologicznej. Nie był to zresztą problem tylko narodowych demokratów: J. Szacki pisał, że „nie ma bodaj drugiego pytania nauk społecznych, na które udzielano by równie sprzecznych odpowiedzi”, J. Szacki, Kłopoty z pojęciem narodu, w: Humanistyka przełomu wieków, red. J. Kozielecki, Warszawa 1999, s. 150. 
ność interesu narodowego winna iść ponadto w parze z koniecznością stałej walki o pomnożenie sił narodowych ${ }^{19}$. Balicki pisał, że nieodzownym warunkiem odrodzenia człowieka, zarówno w sferze materii, jak i ducha, jest zespolenie się z narodem, z jego jaźnią i duchowościa, a priorytetowym celem przemian społecznych - zmiana stosunku jednostki do społeczeństwa, do narodu, czyli ukształtowanie w jednostce postawy całkowitej identyfikacji z narodem ${ }^{20}$. Myśl narodowa, wszechpolska wraz z upływem czasu ewoluowała w kierunku coraz mocniej zaznaczającej się dominacji wartości narodu nad wartością jednostki ${ }^{21}$. Naród jako wartość korespondował też i miał bezpośredni wpływ na usytuowanie tradycyjnych autorytetów, przede wszystkim rodziny i państwa ${ }^{22}$.

Narracja publicystyki „Przeglądu Narodowego” korespondowała z założeniami programowymi ruchu; objaśniano, skąd się bierze więź emocjonalna, charakterystyczna dla członków jednego narodu. Wskazywano na czynniki, które legły u podstaw narodowości polskiej, doprowadzając do ukształtowania się poczucia świadomości i tożsamości narodowej - w aspekcie historycznym - począwszy od epoki piastowskiej ${ }^{23}$. Wskazywano, jak w tym kontekście należy rozumieć pojęcia indywidualności narodu i typu narodu. Pisano np.:

„Typ narodowy tkwi we krwi i w duszy, przeto tych głębokich instynktów, które są jego podłożem, tego wrodzonego poczucia nie zastąpią żadne <przekonania> narodowe, nie zastąpi nawet najściślejsze trzymanie się wskazań tradycji. Typ narodu nie tylko przejawia się, lecz i urabia przez cały ciąg jego życia - od kolebki aż do teraźniejszości, i trzeba być mocno zrośniętym z ziemią ojczysta, przeżywać wypadki współczesne jako dalszy ciąg jednego, nieprzerwanego i logicznego rozwoju całych jego dziejów, czuć się gospodarzem własnego kraju, odpowiedzialnym za jego teraźniejszość i przyszłość, - żeby wyczuwać w tradycji czasów i form minionych to, co ma przetrwać i rozwinąć się w pełny typ charakteru narodowego" 24 .

19 Por. Program Stronnictwa Demokratyczno-Narodowego w zaborze rosyjskim, Kraków 1903, s. 10; R. Dmowski, Myśli nowoczesnego Polaka, wyd. 5, Warszawa 1934, s. 93.

20 A. Dawidowicz, Zygmunt Balicki (1858-1916). Działacz i teoretyk polskiego nacjonalizmu, Kraków 2006, s. 237.

21 B. Grott, Formacja intelektualna oraz stosunek do religii i Kościoła twórców ruchu narodowego na przełomie XIX i XX wieku, „Almanach Historyczny” 2004, 6, s. 197.

${ }^{22}$ W. Wojdyło, Wychowanie jako kreatywny instrument budowy systemu wartości w myśli społeczno-politycznej obozu narodowego, w: Wychowanie a polityka. Cele polityczne jako czynnik determinujący oddziaływanie wychowawcze, red. G. Radomski, K. Kalinowska, Torun 2003, s. $49-50$.

23 Geneza narodowości polskiej (Z Prasy), „PN” 1908, 1, 3, s. 384.

24 Z. Balicki, Zachowanie typu narodowego, "PN" 1909, 2, 8, s. 134. 
Wyjaśniano czytelnikom, że pojęcie „duszy polskiej” jest realne i właściwe, że są to pewne właściwości, atrybuty, wady i zalety naszego narodu: „Dusza narodu to synteza historii jego czynów zbiorowych”25. Ma ona wpływ na życie społeczne i życie polityczne. Na podstawie analizy czynów zbiorowych narodu polskiego wskazywano, że do cech naszego narodu należą: indywidualizm, demokratyzm, republikanizm, tolerancja, odwaga cywilna, konfederatyzm, patriotyzm i ideowość. „Oto co nam historia wszczepiła w krew, co się stało duszą dusz naszych" ${ }^{26}$. Zwracano uwagę, że świadomość narodowa nie jest procesem czysto intelektualnym, ale historycznym, że rodzi się na przestrzeni dziejów „przez doświadczenia trybem powolnego dojrzewania" ${ }^{27}$. Pisano, że dojrzałość polityczną i siłę wewnętrzną naród powinien zdobywać nie tylko w obliczu ucisku, zagrożenia zewnętrznego, ale także - a może przede wszystkim - „siłą wewnętrzną", czyli wysiłkiem, pracą u podstaw świadomości narodowej, praca, która może zorganizować społeczeństwo w ciało polityczne, nawet pomimo braku państwowości ${ }^{28}$. Według endeckich publicystów, ogromną rolę $\mathrm{w}$ procesie kształtowania tożsamości narodowej pełnią tradycja i kultura, w których „spoczywa siła Polaków”29. Ale, jak podkreślano, jeszcze ważniejsze jest ścisłe zespolenie historii z teraźniejszością ${ }^{30}$. Teraźniejszość winna polegać na nieustannym wykonywaniu testamentu pozostawionego przez tych, którzy przed wiekami nadali naszemu narodowi osobowość, wyodrębnili go spośród innych narodów w postaci państwa, a także nakreślili drogi jego rozwoju. Podkreślano także, że na formowanie i pielęgnowanie tożsamości narodowej ma wpływ nie tylko znajomość dziejów własnej ojczyzny, ale także świadomość roli, jaką w wyrażaniu duszy narodu pełnią: język ojczysty, mowa ojczysta i literatura. Tę świadomość - funkcjonowania języka jako elementu łączącego przeszłe pokolenia ze współczesnymi w jeden naród - winno się wpajać szczególnie młodym pokoleniom, rozwijać w ten sposób „intuicję historyczną”. Jeśli zaś chodzi o literaturę - należy podsuwać młodym ludziom taką, która nie jest naśladownictwem literatur obcych i która odbija nieskażoną niczym duszę naszego narodu ${ }^{31}$.

W artykułach zwracano także uwagę na czynniki wpływające na poczucie dumy z przynależności do narodu polskiego i na rolę tych czynników

25 G. Olechowski, W poszukiwaniu duszy polskiej, „PN” 1912, 5, 10, s. 343.

26 Ibidem, s. 361.

27 Wejdźmy w siebie! (Z Prasy), „PN” 1912, 5, 9, s. 324-325.

28 Ibidem, s. 326.

29 N. Ogończyk, Stosunki etnograficzne na Litwie, „PN” 1910, 3, 2, s. 150.

30 Kult tradycji narodowych (Z Prasy), „PN” 1909, 2, 8, s. 252-253.

31 Z. Balicki, Zasady wychowania narodowego, „PN” 1909, 2, 10, s. 386-388. 
w kształtowaniu tożsamości narodowej. Pisano, że naród, który zatraca poczucie swej godności, poczucie honoru zbiorowego, dumy narodowej, traci jedną z najważniejszych podstaw moralnych swej tożsamości. Podkreślano, że obrona honoru narodu nie dotyczy tylko jednego, własnego pokolenia, ale chodzi o to, ,żeby przyszłe pokolenia mogły sztandar narodowy mocno w ręku utrzymać i wysoko nosić"32. Jako podsumowaniem posłużyć się można wypowiedzią Kozickiego, który stwierdził, że wzrost świadomości narodowej wśród Polaków wzmaga ich patriotyzm, rozwija kulturę narodowa, indywidualizm narodu i w efekcie - pragnienie odzyskania niepodległości ${ }^{33}$.

Doceniając rolę i znaczenie tradycji, dość często na łamach „Przeglądu Narodowego" publikowano artykuły o tematyce historycznej. Wśród ich autorów byli wybitni współcześni historycy, m.in. Ignacy T. Baranowski, Kazimierz Bartoszewicz, Edward Bogusławski, Franciszek Rawita-Gawroński, Władysław Horodyński, Jan Karol Kochanowski, Władysław Konopczyński, Jan Kucharzewski, Aleksander Kraushar, Henryk Radziszewski i Adam Szelągowski. Jak zauważyła Urszula Jakubowska, większość tekstów prezentowała tzw. „optymistyczną wizję historii”, polegającą na nieskupianiu się na klęskach narodowych i trudnych okresach w dziejach państwa i narodu.

Analizę spuścizny publicystycznej Narodowej Demokracji w poszukiwaniu twórczej recepcji tradycji powstańczych - i szerzej - nawiązań do myśli romantycznej - przeprowadzili m.in. Krzysztof Kawalec ${ }^{34}$, Michał Strzelecki ${ }^{35}$ i Katarzyna Wrzesińska ${ }^{36}$. Ta ostatnia wykazała, że choć narodowi demokraci niejako programowo odżegnywali się od podejmowania walki zbrojnej, a opowiadali się za tzw. „polityką realną", to jednak, szukając własnej drogi do odzyskania niepodległości, inspirację czerpali ze spuścizny romantycznej, syntetyzując ją z bliższą im mentalnie tradycją pozytywistyczną ${ }^{37}$. Widać to także w publicystyce „Przeglądu Narodowego": nie gloryfikowano bowiem nawet zwycięskich walk, a skupiano się

32 O godności narodowej (Z Prasy), „PN” 1914, 7, 1, s. 104.

33 S. K. [S. Kozicki], Nacjonalizm, „PN” 1911, 4, 10, s. 377.

34 K. Kawalec, Narodowa Demokracja wobec tradycji powstań narodowych, w: Póki my żyjemy...: tradycje insurekcyjne w myśli polskiej, red. J. Kloczkowski, Warszawa 2004, s. 85-102. Autor skupił się przede wszystkim na recepcji tradycji romantycznej w międzywojennej publicystyce narodowodemokratycznej.

35 M. Strzelecki, W kręgu przeszłości, teraźniejszości i przyszłości. Tradycja w ujęciu nacjonalistycznej publicystyki politycznej do 1939 roku, w: Marzyciele, s. 161-175.

${ }^{36}$ K. Wrzesińska, Naród jako duchowa wspólnota pokoleń: ku syntezie pozytywizmu i romantyzmu w myśli Narodowej Demokracji okresu zaborów, w: Rok 1863: narodziny nowej Polski, M. Rudaś-Grodzka et al., Warszawa 2016, s. 48-68.

37 Ibidem, s. 49-50. 
na osiągnięciach narodu w dziedzinie kultury i ekonomii, przypominając zdolności i umiejętności organizacyjne wybitnych osobistości ${ }^{38}$. Taki wydźwięk miały np. artykuły H. Radziszewskiego i Żelisława Grotowskiego o działalności politycznej i gospodarczej Franciszka Ksawerego Druckiego-Lubeckiego ${ }^{39}$, czy tekst tego pierwszego o reformach podatkowych i darach społeczeństwa przekazywanych Bankowi Polskiemu na wydatki związane $\mathrm{z}$ wojskiem $\mathrm{w}$ okresie powstania listopadowego ${ }^{40}$. W podobnym tonie utrzymane były też teksty Władysława Konopczyńskiego o działalności Stanisława Konarskiego ${ }^{41}$ i biskupa Adama Stanisława Krasińskie$\mathrm{go}^{42}$. Wielokrotnie przypominano osiągnięcia gospodarcze, społeczne i kulturalne z czasów Księstwa Warszawskiego oraz Królestwa Kongresowego i Królestwa Polskiego po 1832 r. ${ }^{43}$ W objaśnianiu tej linii redakcyjnej „Przeglądu Narodowego" Jakubowska powołuje się na twierdzenie Jerzego Maternickiego, który wskazywał na tendencję, obecną w publicystyce i historiografii narodowodemokratycznej w latach 1907-1914, w myśl której „optymizm” stał się jednym z narzędzi integracji społeczeństwa polskiego i kształtowania jego opinii w duchu haseł solidarystycznonarodowych. Jakubowska zaznacza jednak, że idea integracji i solidarności społecznej była obecna w wypowiedziach przywódców obozu narodowego również wcześniej ${ }^{44}$.

Choć na łamach miesięcznika pojawiały się także artykuły nawiązujące do bolesnych kart w historii, np. do zakończonych klęską powstań narodowych, to te aspekty dziejów narodowych miały na celu coś innego - pokazanie, że trzeba szukać innych niż walka zbrojna dróg do odzyskania niepodległości. Jak słusznie wykazał M. Strzelecki, selektywny dobór tekstów historycznych w publicystyce endeckiej służył temu, by wartość

38 U. Jakubowska, "Przeglad, s. 104.

39 H. Radziszewski, Polityka Lubeckiego, „PN” 1908, 2, 12, s. 668-687; Ż. Grotowski, Czynniki rozwoju gospodarczego w Królestwie Kongresowym (1815-1830), [cz. 1], „PN” 1911, 4, 8, s. 216-227.

${ }^{40}$ H. Radziszewski, Skarb w okresie rewolucji listopadowej, „PN” 1908, 1, 9, s. 264-298; idem, Bank Polski w okresie rewolucji listopadowej, „PN” 1909, 2, 12, s. 651-690.

41 W. Konopczyński, Stanistaw Konarski jako reformator polityczny, „PN” 1908, 1, 1, s. 14-43.

42 Idem, Biskupa Adama Krasińskiego traktat o naprawie Rzeczypospolitej, „PN” 1913, 6, 4, s. 345-359; 5, s. 492-515.

43 Ż. Grotowski, Czynniki, [cz. 1], „PN” 1911, 4, 8, s. 216-227; [cz. 2], „PN” 1911, 4, 9, s. 345-357, [cz. 3], „PN” 1911, 4, 10, s. 465-479; idem, Stosunki społeczno-gospodarcze w dobie utworzenia Królestwa Kongresowego, „PN” 1912, 5, 5, s. 499-512; 6, s. 599-613; J. Gościcki, Ruch wspótdzielczy, „PN” 1910, 3, 8, s. 129-139; S. Jasiukowicz, Zarys dziejów powstania Towarzystwa Kredytowego Ziemskiego, [cz. 1], „PN” 1911, 4, 8, s. 121-156; [cz. 2], „PN" 1911, 4, 9, s. 250-284; S. Dzierzbicki, Rolnictwo nasze w ubiegłym dwudziestopięcioleciu, „PN" 1911, 4,5, s. 513-528.

${ }_{44}$ U. Jakubowska, "Przeglad, s. 103-104. 
dziedzictwa konstruktywnie przetworzyć dla dobra narodu, wyzyskać jego pozytywne elementy, przy jednoczesnym odrzuceniu błędów popełnianych w przeszłości ${ }^{45}$.

Druga grupa tekstów publicystycznych traktowała o problemie jedności narodowej, rozumianej na dwa sposoby: jako jedności wszystkich warstw - klas społecznych narodu, oraz jako jedności Polaków we wszystkich zaborach. Zgodnie ze stanowiskiem Narodowej Demokracji, wielokrotnie wyrażanym w publicystyce przywódców ruchu oraz w programach Stronnictwa Demokratyczno-Narodowego, jednym z najważniejszych problemów i zadań stojących przed społeczeństwem polskim było jego zjednoczenie, czyli zlikwidowanie nadmiernego dystansu pomiędzy klasami. Publicyści „Przeglądu Narodowego” piętnowali więc partykularyzm grupowy, który był postrzegany jako czynnik wybitnie negatywnie wpływający na rozwój interesów narodowych, wyniszczający wręcz całą wspólnotę narodowa, a który uwydatniał się tak w sferze robotników fabrycznych, jak i na przeciwnym szczeblu drabiny społecznej, to znaczy w sferze arystokratycznej. Pisano, że w działalności narodowej - o ile ta ma być skuteczna - koniecznym jest podporządkowanie się jej i solidarność narodowa, nie - grupowa, ani nie - klasowa: „Tylko wspólna praca narodowa jednoczy klasy społeczne, tworzy z nich jedną psychiczną całość; gdy takiej pracy nie ma, wówczas klasowa wyłączność dochodzi aż do zupełnej obcości względem tego, co się w narodzie dzieje"46. Takie poglądy narodowych demokratów wynikały z faktu, że do wszystkich kwestii społecznych podchodzili z punktu widzenia interesów ogólnonarodowych i patrzyli na każdą klasę i grupę społeczną przez pryzmat jej przydatności dla rozwoju tożsamości narodu. Naród, konstatowano, jeśli będzie odczuwał swoją odrębność i wyjątkowość wobec innych narodów, to nawet pozbawiony państwa nie zatraci swojej tożsamości ${ }^{47}$. W dobie walki o niepodległość naród polski stanie się organizmem politycznym dopiero wówczas, gdy wszystkie jego warstwy posiądą świadomość życia narodowego ${ }^{48}$. W tym kontekście wyrażano przekonanie o konieczności

${ }^{45}$ M.Strzelecki, op. cit., s. 167. Według autora charakterystyczny sposób interpretowania procesu dziejowego i spuścizny przeszłości, będący w ścisłym związku z całym systemem wartości akceptowanych przez narodowych demokratów oraz z ich wizją ładu społecznopolitycznego, był czynnikiem wyróżniającym refleksję nacjonalistyczną na tle innych nurtów polskiej myśli politycznej.

46 S. B., Bilans sit narodowych, "PN" 1908, 1, 1, s. 67. Na postawy reprezentowane przez burżuazję Popławski zwrócił uwagę dużo wcześniej, bo już w okresie swojej współpracy z "Głosem”, potępiając ją za nadmierną koncentrację wysiłków na interesach jednostkowych, indywidualnych, R. Wapiński, Narodowa, s. 23.

47 I. Baliński, Przypowieść Meneniusza Agryppy, „PN” 1911, 4, 9, s. 243.

48 G. Olechowski, op. cit., s. 363. 
uobywatelnienia warstwy ludowej. Kozicki podkreślał, że dla perspektywy budowy przyszłego, nowoczesnego społeczeństwa polskiego jednym z najważniejszych zadań jest już teraz zjednoczenie warstwy włościańskiej z innymi warstwami narodu, wytworzenie, a raczej utrwalenie wspólnych idei i dążeń, niezbędnych dla istnienia i rozwoju społeczeństwa ${ }^{49}$. Instynkt narodowy nie jest bowiem cechą tylko ludzi wykształconych; coraz szersze warstwy społeczeństwa, w tym włościanie, dochodzą do samowiedzy i społecznej, i narodowej ${ }^{50}$. Jednocześnie podkreślano, że już teraz da się zauważyć pewne przeobrażenia warstwy włościańskiej, że lud wiejski jednoczy się mentalnie $\mathrm{z}$ innymi warstwami narodu, a doświadczenie to jest ważnym czynnikiem kształtowania jego świadomości narodowej. Narzędzi i wpływów na warstwę ludową Kozicki upatrywał w książce i czasopiśmie. Szczególne zasługi przypisywał Konradowi Prószyńskiemu i założonej przez niego „Gazecie Świątecznej”"51 oraz elementarzom dla ludu w jego opracowaniu, które dawały czytelnikom „wiadomości sprawdzone i przetrawione". Kozicki powoływał się też na pismo dla ludu „Zorza" ${ }^{2}$ oraz na rozwijany na łamach warszawskiego „Głosu” program pracy dla ludu, skupiający cały zastęp działaczy na prowincji, którzy czynnie pracowali na polu oświaty ludowej ${ }^{53}$. Wspomniane pisma i działalność związanych z nimi ludzi sprawiły, że w Królestwie Polskim zaczęła się rozwijać wśród ludu wiejskiego dążność do zdobywania wiedzy ogólnej i rolniczej, do ulepszeń w gospodarstwie. Jednocześnie lud zaczął pojmować swoje znaczenie jako najliczniejszej warstwy w narodzie, utożsamiać swoje interesy $\mathrm{z}$ interesami całego narodu, rozumieć istniejące $\mathrm{w}$ kraju stosunki, orientować się w układzie stosunków poza granicami ojczyzny. Kozicki zauważał jednak, że rzetelne odpowiedzi na pytania związane

49 S. Kozicki, Przeobrażenie wsi polskiej, „PN” 1910, 3, 4, s. 386. Por. K. Wrzesińska, Naród, s. 62.

50 Z. Balicki, Zachowanie, s. 139.

51 "Gazeta Świąteczna" - popularno-oświatowy tygodnik dla ludu, wydawany w latach 1881-1939 w Warszawie, którego twórcą był pisarz i działacz oświatowy Konrad Prószyński (pseud. Kazimierz Promyk).

52 "Zorza" - pismo dla ludu, wydawane w Warszawie w latach 1866-1905, założone przez Józefa Grajnerta - działacza oświatowego, etnografa i pisarza. Zob. Z. Kmiecik, Z dziejów pism dla ludu (1866-1905). („Zorza i Gazeta Świateczna”), "Rocznik Historii Czasopiśmiennictwa Polskiego" 1966, 5, 1, s. 84-102. Oba czasopisma - „Zorza” i „Gazeta Świąteczna" zostały pozyskane dla ruchu narodowego.

53 "Głos" - tygodnik społeczno-polityczny i literacki (1886-1899), założony m.in. przez J.L. Popławskiego i Józefa Karola Potockiego. Początkowo o tendencjach lewicowych, z czasem znalazł się pod wpływem Ligi Polskiej, a potem Ligi Narodowej. Zob. "Głos" 1886-1899. Bibliografia zawartości, oprac. Z. Biłek, M. Kukulska, R. Loth, Wrocław 1955; N. Bończa-Tomaszewski, Demokratyczna geneza nacjonalizmu. Intelektualne korzenie ruchu narodowo-demokratycznego, Warszawa 2001. 
z otaczającą rzeczywistością społeczną i polityczną: o tym co w gminie, urzędzie, w wojsku, dawały przede wszystkim nielegalne czasopisma przywożone z Galicji. Z wydawnictw tych najwyższe uznanie zdobył sobie „Polak" 54 i wydawane przez jego redakcję odezwy i broszury, na które popyt wzrastał z roku na rok. To one szerzyły oświatę i ducha niepodległości na całym obszarze ziem polskich, a przede wszystkim w zaborze rosyjskim ${ }^{55}$. Kozicki przypominał też, że ogromnym krokiem naprzód w kierunku społecznego uświadomienia warstwy włościańskiej było jej uwłaszczenie (1823 - zabór pruski, 1848 - Galicja, 1864 - Królestwo Polskie). Miało ono ogromny wpływ na działania dążące do uświadomienia narodowego warstw ludowych, a rozwijająca się we wszystkich zaborach praca organiczna przekształciła je w nowożytne społeczeństwo, jednoczące się we wspólnej pracy i walce narodowej z pozostałymi warstwami narodu. To sprawiło, że w połowie pierwszego dziesięciolecia XX w. warstwa chłopska była najliczniejsza, że posiadała większą część ziemi w swym władaniu, że wyznawała te same ideały, co inne warstwy, i była przejęta tymi samymi dążnościami, co większa własność, mieszczaństwo i warstwy robotnicze. Kozicki sugerował nawet, że warstwa włościańska wysunęła się na pierwszy plan w ekonomicznej i społecznej walce o podstawy bytu narodowego, toczonej na całym obszarze ziem polskich, m.in. z Niemcami, Rusinami i Żydami, i przede wszystkim ona sama ponosi ciężar tej walki ${ }^{56}$.

Sprawa fascynacji ideologów Narodowej Demokracji ludem wymaga pewnego komentarza. Kwestię tę wyjaśnił Roman Wapiński: otóż poja-

54 „Polak” - pismo wydawane od 1896 r. przez Ligę Narodową w Galicji, ale z przeznaczeniem dla warstwy włościańskiej w zaborze rosyjskim. Redaktorem miesięcznika był Kasper Wojnar, a faktycznym ideologiem pisma - J.L. Popławski, którego swoimi tekstami wspomagał R. Dmowski. Celem pisma było kształtowanie świadomości narodowej chłopów i przygotowywanie ich do roli świadomych uczestników przyszłych walk o wyzwolenie narodowe. Zob. W. Piątkowski, Idee społeczno-polityczne "Polaka" (1896-1906). Przyczynek do kształtowania się ideologii Narodowej Demokracji, "Rocznik Historii Czasopiśmiennictwa Polskiego" 1966, 5, 2, s. 45-65.

55 S. Kozicki, Przeobrażenie, s. 386-389.

56 Idem, Przeobrażenia społeczne w Polsce porozbiorowej, „PN” 1914, 7, 3, s. 269. T. Kulak zwróciła uwagę na to, jak ważna w podnoszeniu społecznej roli ludu była wiara $\mathrm{w}$ jego instynkt narodowy i wrodzony patriotyzm, weryfikowany przywiązaniem do własnej ziemi, parafii, okolicy. W miarę rozszerzania się programu niepodległości i równoczesnego zaostrzenia polityki antypolskiej Rosji i Niemiec restytucję niepodległości Polski utożsamiano z siłą odpornej na wynarodowienie warstwy włościańskiej, broniącej każdego kawałka polskiej ziemi, T. Kulak, Mit narodowej siły polskiego ludu, w: Polskie mity polityczne XIX i XX wieku, red. W. Wrzesiński, Wrocław 1994, s. 161-162. Kompleksowo problematykę stosunku Narodowej Demokracji do kwestii chłopskiej omówił T. Wolsza w monografii: Narodowa Demokracja wobec chtopów w latach 1887-1914. Programy, polityka, działalność, Warszawa 1992. 
wiające się w jej programach i publicystyce hasła demokratyzacji stosunków społecznych i politycznych oraz aktywizacji politycznej mas ludowych nie były celem samym w sobie. Demokratyzacja społeczeństwa była dla endeków przede wszystkim warunkiem niezbędnym do upowszechniania ideologii nacjonalistycznej. Nie znaczy to jednak, że traktowali ją całkowicie instrumentalnie. Zdawali sobie także sprawę, że na rozwój świadomości narodowej nędza społeczna wpływa ujemnie, podobnie jak odsunięcie mas od wpływu na bieg wydarzeń politycznych i utrzymywanie się dystansu między tymi masami a klasami posiadającymi, będące pozostałością po społeczeństwie stanowym. Narodowi demokraci woleli mieć do czynienia ze społeczeństwem bardziej jednolitym pod względem statusu, bo takie społeczeństwo uważali za lepiej podatne na akceptację ich ideologii, której integralną część stanowiły m.in. hasła solidaryzmu społecznego, ale podporządkowanego nacjonalistycznie pojmowanemu interesowi narodowemu - stąd bardziej adekwatnym pojęciem jest: solidaryzmu narodowego. Akcentowanie konieczności demokratyzacji stosunków oraz potrzeby uwzględniania interesów mas ludowych warunkowane było także słabością wpływów endecji wśród klas posiadających, przynajmniej w okresie do $1905 \mathrm{r} .{ }^{57}$

Z przemianami, jakie dokonywały się w życiu ludu wiejskiego wiązał się także postulat objęcia go swego rodzaju patronatem przez inteligencję. Od zrozumienia i przyjęcia przez nią tych licznych i ważnych obowiązków oraz od właściwego ich spełniania uzależniano dalszą przyszłość narodu jako jedności. Mając świadomość swojego wykształcenia (lepszego niż ogół społeczeństwa) i tym samym uprzywilejowanej pozycji, inteligencja postulowano - winna wpływać na jakość i kształt życia społecznego, politycznego i kulturalnego ludu, obejmując jak gdyby nad nim swoiste przywództwo duchowe. Na inteligencję nakładano obowiązek organizowania, wychowywania, oświecania ludu, a szerzej - kierowania rozwojem życia umysłowego, torowania drogi nowym tendencjom, prądom społecznym i umysłowym, słowem - swoistej opieki, patronowania nad tworzeniem i pomnażaniem ogólnego dorobku duchowego społeczeństwa ${ }^{58}$.

57 R. Wapiński, Narodowa, s. 48.

58 S. Kozicki, Przeobrażenie, s. 393. Por. Z. Wójcik, Rozwój pojęcia inteligencja, Wrocław 1962, s. 38. Inteligencja związana z ruchem narodowym odegrała ogromną rolę w rozwoju polskiej kultury i oświaty w omawianym okresie. Była uczestnikiem (odbiorcą) kultury, a zarazem twórcą i organizatorem różnych przedsięwzięć na tym obszarze. Uplasowana na szczycie piramidy społecznej, inteligencja tworzyła kulturę masową i narodową. Do najważniejszych przedsięwzięć z udziałem inteligencji należy zaliczyć także wszelkie inicjatywy związane z prasą i książką. Za pośrednictwem tych mediów do społeczeństwa docierały treści ideologiczne. Por. K. Wrzesińska, Kultura. 
Z kolei w wyniku uprzemysłowienia ziem polskich, jakie dokonało się w XIX w. wyodrębniła się nowa warstwa społeczna - robotnicy. Warstwa ta, choć niewątpliwie - według Kozickiego - ma instynktowne poczucie polskości i zrozumienie interesów narodowych, nadal potrzebuje inspiracji i pomocy w zakresie kształtowania tożsamości narodowej ${ }^{59}$.

Jak już wspomniano, oprócz haseł jedności wszystkich warstw społecznych, publicyści „Przeglądu Narodowego” głosili hasła jedności Polaków we wszystkich zaborach. W wielu tekstach podkreślano więc konieczność uświadomienia Polakom, że wszyscy, bez względu na to, w którym zaborze żyją, stanowią jeden, niepodzielny naród. Kwestię budowania samowiedzy narodowej, "organizowania swojej siły duchowej”, uważano za najważniejsze wspólne zadanie, stojące przed społeczeństwem wszystkich dzielnic $^{60}$. Wyzwolenie narodu - rozpatrywane w kategoriach suwerenności prawno-politycznej - może nastąpić jedynie poprzez uświadomienie sobie przez naród polski we wszystkich zaborach odrębności swych interesów politycznych, gospodarczych i kulturalnych oraz konieczności prowadzenia o nie codziennej, systematycznej walki - w każdym z nich ${ }^{61}$.

Trzecią, bardzo ważną grupę stanowiły artykuły, w których dokonywano swego rodzaju redefinicji patriotyzmu w kontekście jego roli w procesie kształtowania świadomości narodowej Polaków. Pisano, że przez całe ostatnie stulecie patriotyzm polski zwracał się ku czynom wojennym: z jednej strony żył wspomnieniem walk przeszłości, z drugiej - nadzieją na ich wznowienie w przyszłości. Ponadto, wskutek znanych przyczyn historycznych, patriotyzm był ograniczony do jednej tylko warstwy społecznej - szlachty. Wraz z klęską powstania, klęskę poniósł program walk zbrojnych, który dotychczas stanowił całą treść patriotyzmu. Razem $\mathrm{z}$ tym programem zbankrutował więc patriotyzm ${ }^{62}$. W opinii narodowych demokratów upadek powstania styczniowego skutkował nie tylko stratami materialnymi, ale przyniósł także społeczną apatię i depresję moralną ${ }^{63}$. Polacy zatracili instynkt tworzenia, umiejętność świadomego budowania przyszłości, utracili zdolność do podejmowania wysiłków w ich

59 S. Kozicki, Przeobrażenia, s. 270-275.

60 Wejdźmy, s. 324.

61 J. Sieniuta, Węły ekonomiczne, „PN” 1908, 1, 2, s. 94-95. Kilka lat wcześniej Dmowski stwierdził, że problem niepodległości tak naprawdę obejmuje dwie kwestie, ponieważ Polska nie tylko została pozbawiona samoistnego bytu politycznego, ale też podzielona między trzy państwa. Sprawa niepodległości musi więc objąć dwa cele: zjednoczenie państwowe ziem polskich oraz zdobycie niepodległości, Narodowiec [R. Dmowski], W naszym obozie, „Przegląd Wszechpolski” 1907, 7, 7, s. 421.

62 A. Sadzewicz, Przeistoczenie się patriotyzmu, „PN” 1909, 2, 11, s. 513-514

63 Do tego dodać można jeszcze eliminację bardzo poważnej części najbardziej aktywnych grup społecznych, wyczulonych na krzywdę narodową i społeczną oraz 
historycznej ciągłości, przechodzącej z pokolenia na pokolenie. Taki stan rzeczy był poniżający, budził niezadowolenie wielu środowisk ${ }^{64}$. Musiał upłynąć pewien czas, aby zrozumiano, że przyszłość narodu, a nawet samo zagadnienie jego bytu rozegra się nie na polu walki zbrojnej o niepodległość, lecz na polu walki ekonomicznej, walki o ziemię, o dom, o placówki w przemyśle i w handlu ${ }^{65}$. Toteż, gdy walki zbrojne jako środek odzyskania niepodległości zostały wykreślone z realnych programów politycznych $^{66}$, patriotyzm polski winien gruntownie się przeistoczyć, przystosować do zmieniających się warunków bytu narodowego, ale rozwijać się z uwzględnieniem wszystkich warstw społecznych oraz „zejść na niziny życia powszedniego, winien stać się realnym" ${ }^{\prime 67}$. Wypowiedzi te korespondowały z postulatem Dmowskiego, by w warunkach braku własnego państwa, stawiając sobie za cel jego odbudowanie, odwoływać się do idei wspólnoty narodowej, ale przede wszystkim prowadzić codzienną działalność, która mogłaby wzmacniać żywioł polski ${ }^{68}$, oraz z jego tezą o konieczności pomnażania sił narodowych - nawet już w warunkach niepodległości, która nie powinna zamykać walki narodowej. Za podstawowy instrument tej ostatniej uznany więc został ruch organicznikowski ${ }^{69}$.

Odejście od powstańczych koncepcji $\mathrm{w}$ pewnym sensie przyniosło także dobre skutki, przyczyniło się bowiem do pozytywnych przeobrażeń społeczno-politycznych ${ }^{70}$. Zrozumiano, że patriotyzm nie polega jedynie na zachowywaniu języka, wiary i obyczajów przeszłych pokoleń, znajomości historii narodu, ale na umiejętności pracy, zaangażowaniu się w działania cokolwiek "przyziemne”, takie jak handel, przemysł i rze-

kryzys koncepcji dominujących dotychczas w polskim życiu politycznym, nie tylko tych związanych z ideą powstańcza, R. Wapiński, Narodowa, s. 21.

${ }^{64}$ K. Bohotyński [Z. Balicki], Kierownictwo polityczne, „PN' 1914, 7, 2, s. 117.

65 Poglądy te bazowały na światopoglądzie pozytywistycznym, polegającym na koncentracji uwagi społeczeństwa na sprawach rozwoju ekonomicznego kraju, na podnoszeniu stopnia zamożności wszystkich warstw społecznych, obronie pozostałych jeszcze legalnych form życia społecznego oraz na pogłębianiu solidarności narodowej.

${ }^{66}$ O szkodliwości wysuwania haseł powstańczych publicyści endeccy pisali już na początku XX w., uznając, że współczesna sytuacja wyklucza ten środek taktyczny, przynajmniej na pewien czas, z politycznych przedsięwzięć. Stwierdzenie to znalazło się także w Programie Stronnictwa Demokratyczno-Narodowego dla zaboru rosyjskiego z $1903 \mathrm{r}$.

67 A. Sadzewicz, Przeistoczenie, s. 513-514; Z. Balicki, Dwa patriotyzmy, „PN” 1913, 6, 4, s. 340-341; Z. Balicki, Złoty róg, „PN” 1910, 3, 2, s. 137.

68 R. Wapiński, Roman Dmowski, wyd. 2, Lublin 1988, s. 101.

69 Tyle, że postulowany przez Dmowskiego i innych przywódców endeckich charakter ruchu organicznikowskiego uzyskał sankcję ideologiczną - w porównaniu $\mathrm{z}$ pracą propagowaną przez pozytywistów warszawskich w latach siedemdziesiątych XIX w. - zaś jego efektem nie miało już być podniesienie na wyższy poziom materialny i kulturalny społeczeństwa w ogóle, a jedynie własnego narodu, R. Wapiński, Narodowa, s. 42.

${ }^{70}$ K. Wrzesińska, Naród, s. 56-57. 
miosło. Konieczność tę odkryto najwcześniej w zaborze pruskim, gdzie byt narodowy zagrożony był najbardziej, u podstaw biologicznych, gdzie środkami państwowymi przeprowadzano systematyczną akcję kolonizacyjną. W następnej kolejności ten „nowy patriotyzm” zaczął wkraczać do życia ekonomicznego w Galicji i w Królestwie ${ }^{71}$. Była to świadomość znacząca, szczególnie w warunkach, gdy na tożsamość narodową nastawały nie tylko rządy i szeroko pojęta administracja państw zaborczych, ale także zwykła ludność tych państw, kierowana swoim własnym interesem narodowym ${ }^{72}$. Ten rodzaj patriotyzmu nazywano więc patriotyzmem świadomym.

O konstruktywną pracę na rzecz narodu upominano się szczególnie w warunkach, kiedy Europa nie była już przejęta, ani nawet zainteresowana polskimi marzeniami o wolności, kiedy zobojętniała na nasz los. Dlatego trzeba jej na nowo o sobie przypomnieć - ale nie odgrzebując dawne marzenia i tęsknoty, nie ideologią i "głodem sprawiedliwości", ale innymi zgoła dowodami żywotności Polski i Polaków - Europie "potrzeba znaków widomych naszej cywilizacyjnej i kulturalnej wartości, naszej samodzielności i dojrzałości gospodarczej, naszych dorobków na każdym polu pracy zbiorowej, naszej wewnętrznej spoistości i sprawności) w działaniu"73. Publicysta z optymizmem podkreślał jednak, że obecne pokolenie rozumie już konieczność budowania przyszłej ojczyzny na rzeczywistych, a nie wymarzonych podstawach i jest świadome zadań, które czekają: „,Jest cały ogromny szmat pracy codziennej - pisano - którą musimy odrobić, bo inaczej spadniemy do roli trzecio- i czwartorzędnego czynnika, z którym nikt i nigdy liczyć się nie będzie. [...] Bądźmy [...] pracowici, oszczędni, gospodarni i budujmy Polskę [...] w granicach tej rzeczywistości, jaka jest naszym udziałem obecnym, w przekonaniu, iż granice te rozszerzać będzie każdy dzień < dobrze przeżyty>, każda godzina, poświęcona pracy"74. Budowanie Polski w granicach rzeczywistości rozumiano jako pracę dla niej, z myślą o jej przyszłości. Wyrażano opinię, że tylko świadome społeczeństwo zrozumie i doceni wartość aktywności, codziennych, bieżących działań umożliwiających uzyskanie w każdej

71 A. Sadzewicz, Przeistoczenie, s. 514-519.

72 S. Kozicki, O podstawy bytu narodowego, „PN” 1911, 4, 1, s. 7. W publicystyce endeckiej zwracano uwagę na zawodność liczenia na współdziałanie narodu polskiego z rosyjskim i niemieckim oraz na swego rodzaju naturalność polityki rusyfikacyjnej i germanizacyjnej, na to, że polityka każdego narodu w stosunku do innych narodowości jest zaborcza i polega albo na zdobywaniu nowych terytoriów, albo na dążeniu do odzyskania utraconych, R. Wapiński, Narodowa, s. 36.

73 Poczucie rzeczywistości (Z Prasy), „PN” 1913, 3, 1, s. 104.

74 Ibidem, s. 104-105. 
dzielnicy jak największego zakresu samodzielności narodowej-a w przyszłości - niepodległości państwa ${ }^{75}$.

Śledząc teksty publicystyczne definiujące i redefiniujące pojęcie patriotyzmu, nie sposób pominąć tych, które wskazywały - według ich autorów - na najwyższą jego formę: nacjonalizm. Podczas gdy patriotyzm uważano jedynie za postawę zbiorowa, wynikającą m.in. z poczucia jednorodności, solidarności w obrębie narodu, z przywiązania do wspólnych tradycji, wierzeń, kultury, z poczucia własnej odrębności od narodów otaczających, to nacjonalizm utożsamiano $\mathrm{z}$ narodową myślą, która co prawda nie może powstać ani się rozwijać bez podłoża emocjonalnego, ale stanowi jednak zjawisko bardziej złożone, określane jako prąd umysłowy, powstający w łonie patriotyzmu. W ideologii nacjonalistycznej pisał Balicki - naród ujmuje się jako zbiorowość organiczną posiadającą swoją budowę społeczną i powołaną do stanowienia odrębnej, terytorialnej indywidualności międzynarodowej. Jako prąd narodowo-społeczny nacjonalizm odgrywa ogromną rolę w sytuacji, kiedy interesy narodowe nie są zabezpieczone przez instytucje państwowe, lub państwo czyni to niedostatecznie. $W$ warunkach, $w$ jakich znalazł się naród polski, nacjonalizm pogłębia patriotyzm, sprzyja odrodzeniu narodu, wzmacnia jego wiarę w siebie oraz w swoje siły ${ }^{76}$. Ponadto zachęca i instruuje całe społeczeństwo do zgodnego i solidarnego prowadzenia określonej polityki narodowej, a w miarę, jak jego wskazania są realizowane, „toruje nowe drogi obrony bytu narodowego, bo zadania jego są równie niewyczerpane i nieskończone, jak samo życie postępujące wciąż naprzód"77. Takie właśnie rozumienie nacjonalizmu, prezentowane w publicystyce endeckiej, której wyimek stanowiły teksty w "Przeglądzie Narodowym”, dało podstawę do sformułowania tezy, że jako ideologia polityczna, która się kształtowała na przełomie XIX i XX w., był on traktowany jako: myśl, koncepcja, teoria, a więc był czymś więcej niż patriotyzmem, określanym jako stadium wcześniejsze organizacji narodu. Podczas gdy patriotyzm uważano „jedynie" za uczucie, nacjonalizm nazywano doktryną ${ }^{78}$. Bogumił Grott zwrócił przy tym uwagę na bardzo ważny aspekt badań nad ideą nacjonalizmu: ich prawidłowość zapewnić może jedynie wielowymiarowość, opierająca się na wiedzy z zakresu kultury, religii i duchowości danego narodu. To one bowiem "stanowią glebę, z której wyrasta dopiero ze-

75 A. Sadzewicz, Przeglad spraw polskich, „PN” 1908, 1, 1, s. 83-84.

76 Z. Balicki, Nacjonalizm a patriotyzm, „PN” 1912, 5, 5, s. 451-453.

77 Ibidem, s. 455.

78 B. Grott, Dylematy polskiego nacjonalizmu. Powrót tradycji czy przebudowa narodowego ducha, Warszawa 2014, s. 21. 
spół idei oraz metody działania charakteryzujące dany ruch"79. Zarówno w publikacjach o charakterze źródłowym, jak i w pracach podejmujących analizę ideologii nacjonalizmu wielokrotnie podkreślano, że idee nacjonalizmu miały ogromny wpływ na kształtowanie tożsamości narodowej, szczególnie w warunkach, gdy naród pozbawiony był państwowości.

Analiza treści artykułów wypełniających łamy „Przeglądu Narodowego" wskazuje, że podejmowany w nich wątek integracji społeczeństwa polskiego wszystkich zaborów oraz kształtowania poczucia jedności narodowej, kształtowania świadomości narodowej, troski o rozwój i tożsamość narodu polskiego, zajmował ważne miejsce. Wypowiadali się w tych kwestiach czołowi ideolodzy, działacze i sympatycy Narodowej Demokracji. Wiele tez zawartych $\mathrm{w}$ cytowanych artykułach było tożsamych z publicystyką programową przywódców ruchu, przede wszystkim Zygmunta Balickiego, Romana Dmowskiego i Stanisława Kozickiego. Wydaje się, że mógł to być zabieg celowy, gdyż prasa zawsze miała większe grono odbiorców niż książka, a chodziło przecież o to, aby z ideami ruchu zapoznać jak najszersze kręgi społeczeństwa. „Przegląd Narodowy” organizował więc opinię publiczną wokół ideologii narodowodemokratycznej, ale także uczył „nowego patriotyzmu”, polegającego na wytężonej pracy w aktualnych warunkach, ale z myślą o przyszłości niepodległego państwa.

\section{REFERENCES (BIBLIOGRAFIA)}

\section{Political programs (Programy polityczne)}

Program Stronnictwa Demokratyczno-Narodowego w zaborze rosyjskim, Kraków 1903.

Program Stronnictwa Demokratyczno-Narodowego w zaborze rosyjskim, „Przegląd Wszechpolski" $1897,11$.

79 Ibidem, s. 23. Grott za niewystarczające uznał np. badania realizowane przez historyków, którzy skupiają się na wydarzeniach dotyczących działalności partii nacjonalistycznych i ich liderów, a więc uprawiających tzw. historię wydarzeniowa, czy przez politologów, którzy z kolei zajmują się przede wszystkim zagadnieniami władzy politycznej oraz instrumentami służącymi do jej zdobycia i utrzymania. Zwrócił ponadto uwage na stosunek ideologów narodowodemokratycznych do religii i Kościoła katolickiego, którzy - przy całej złożoności tej problematyki - stali na stanowisku, że religia katolicka ma doniosłe znaczenie w życiu społeczeństwa polskiego, a wręcz - w pewnych warunkach - jest symbolem polskości. Szczególnie później, w latach trzydziestych, była ona ważnym elementem tożsamości narodowej. Ale nawet wartość katolicyzmu narodowi demokraci podporządkowywali wartości narodu, traktowanej jako nadrzędna. Por. B. Grott, Religia, Kościót, etyka w ideach i koncepcjach prawicy polskiej. Narodowa Demokracja. Wybór tekstów z komentarzem autora, Kraków 1993, s. 12-14; idem, Formacja, s. 202-206. 


\section{Press (Prasa)}

„Przegląd Narodowy” 1908-1914.

„Przegląd Wszechpolski” 1897, 1907.

\section{Studies (Opracowania)}

Białokur M., Stosunki polsko-ukraińskie w Galicji na łamach "Przegladu Narodowego" (19081914), „,Rocznik Historii Prasy Polskiej” 2002, 2.

Bończa-Tomaszewski N., Demokratyczna geneza nacjonalizmu. Intelektualne korzenie ruchu narodowo-demokratycznego, Warszawa 2001.

Dawidowicz A., "Przeglad Narodowy” 1908-1914; 1919-1921, w: Prasa Narodowej Demokracji (1886-1939), red. A. Dawidowicz, E. Maj, Lublin 2010.

Dawidowicz A., Droga do niepodległości Polski w myśli politycznej Narodowej Demokracji, „Myśl Ludowa” 2013, 5.

Dawidowicz A., Problematyka narodowa w myśli politycznej Zygmunta Balickiego, „Polityka i Społeczeństwo" 2004, 1.

Dawidowicz A., Rola prasy w rozwoju Narodowej Demokracji (1893-1939), w: Polityka i politycy w prasie XX i XXI wieku, red. M. Dajnowicz, A. Miodowski, Białystok 2016.

Dawidowicz A., Stan badań nad dziejami i myśla polityczna Narodowej Demokracji, "Atheneaum" 2012, 33.

Dawidowicz A., Zygmunt Balicki (1858-1916). Działacz i teoretyk polskiego nacjonalizmu, Kraków 2006.

Dmowski R., Myśli nowoczesnego Polaka, wyd. 5, Warszawa 1934.

„Głos" 1886-1899. Bibliografia zawartości, oprac. Z. Biłek, M. Kukulska, R. Loth, Wrocław 1955.

Grott B., Dylematy polskiego nacjonalizmu. Powrót tradycji czy przebudowa narodowego ducha, Warszawa 2014.

Grott B., Formacja intelektualna oraz stosunek do religii i Kościoła twórców ruchu narodowego na przełomie XIX i XX wieku, „Almanach Historyczny” 2006, 6.

Grott B., Religia, Kościót, etyka w ideach i koncepcjach prawicy polskiej. Narodowa Demokracja. Wybór tekstów z komentarzem autora, Kraków 1993.

Jakubiak K., Idea wychowania obywatelskiego w polskiej myśli pedagogicznej przełomu XIX i XX wieku oraz Drugiej Rzeczypospolitej, w: Wychowanie a polityka. Między wychowaniem narodowym a państwowym, red. W. Wojdyło, Toruń 1999.

Jakubowska U., „Przeglad Narodowy” 1908-1914, „Kwartalnik Historii Prasy Polskiej” 1984, 23,3 .

Jakubowska U., Prasa Narodowej Demokracji w dobie zaborów, Warszawa-Łódź 1988.

Kawalec K., Narodowa Demokracja wobec przemian świadomości narodowej Polaków w latach 1918-1939, w: Wrocławskie Studia z Historii Najnowszej, t. 6, red. W. Wrzesiński, Wrocław 1998.

Kawalec K., Narodowa Demokracja wobec tradycji powstań narodowych, w: Póki my żyjemy...: tradycje insurekcyjne w myśli polskiej, red. J. Kloczkowski, Warszawa 2004.

Kizwalter T., O nowoczesności narodu. Przypadek polski, Warszawa 1999.

Kmiecik Z., Z dziejów pism dla ludu (1866-1905). („Zorza i Gazeta Świateczna”), „Rocznik Historii Czasopiśmiennictwa Polskiego" 1966, 5, 1.

Konieczny W., Formowanie i umacnianie świadomości narodowej jako elementarne zadanie polityczne Narodowej Demokracji na przełomie XIX i XX wieku, „Studia Historyczne” 1989, 4.

Kulak T., Mit narodowej sity polskiego ludu, w: Polskie mity polityczne XIX i XX wieku, red. W. Wrzesiński, Wrocław 1994.

Litwinek-Lewandowska D., Elity polityczne Galicji w opinii „Przegladu Narodowego" w latach 19081914, „Annales Universitatis Mariae Curie-Skłodowska. Sectio K, Politologia” 2004, 11. 
Lubczyńska A., "Ateneum Polskie” 1908. „Przeglad Narodowy” 1908-1914. Adnotowana bibliografia zawartości, Kielce 2017.

Maj E., O badaniu myśli politycznej Narodowej Demokracji do roku 1939. Wybrane zagadnienia, „Myśl Polityczna” 2020, 1.

Majchrowski J.M., Kościót i katolicyzm na łamach "Przeglądu Narodowego", "Zeszyty Naukowe Uniwersytetu Jagiellońskiego. Prace Historycznoliterackie" 1986, 55.

Paruzel E., Ideat wychowawczy Narodowej Demokracji i próby jego realizacji na przełomie XIX i XX wieku, Toruń 1993.

Piątkowski W., Idee społeczno-polityczne "Polaka" (1896-1906). Przyczynek do kształtowania się ideologii Narodowej Demokracji, „Rocznik Historii Czasopiśmiennictwa Polskiego” 1966, 5, 2.

Strzelecki M., W kręgu przeszłości, teraźniejszości i przyszłości. Tradycja w ujęciu nacjonalistycznej publicystyki politycznej do 1939 roku, w: Marzyciele i realiści. O roli tradycji w polskiej myśli politycznej od upadku powstania styczniowego do XXI wieku, red. T. Sikorski, A. Wątor, Szczecin 2009.

Szacki J., Kłopoty z pojęciem narodu, w: Humanistyka przełomu wieków, red. J. Kozielecki, Warszawa 1999.

Śmiechowski K., Endeckie postrzeganie miasta. Ewolucja tematyki miejskiej na łamach "Przegladu Wszechpolskiego" i "Przegladu Narodowego", "Studia Podlaskie” 2018, 26.

Walicki A., Naród i terytorium. Obszar narodowy w myśli politycznej Romana Dmowskiego, „Dziś" 2002, 7.

Wapiński R., "Przeglad Wszechpolski” (1895-1905, 1922-1926), w: Na warsztatach historyków polskiej myśli politycznej. Polska myśl polityczna XIX i XX wieku, red. H. Zieliński, Wrocław 1980.

Wapiński R., Idea narodu w myśli społecznej i politycznej endecji przed rokiem 1918, w: Idee i koncepcje narodu w polskiej myśli politycznej czasów porozbiorowych, red. J. Gaćkowski, A. Walicki, Warszawa 1977.

Wapiński R., Narodowa Demokracja 1893-1939. Ze studiów nad dziejami myśli nacjonalistycznej, Wrocław 1980.

Wapiński R., Polska i mate ojczyzny Polaków. Z dziejów ksztattowania się świadomości narodowej w XIX i XX wieku po wybuch II wojny światowej, Wrocław 1994.

Wapiński R., Roman Dmowski, wyd. 2, Lublin 1988.

Wojdyło W., Rola tradycji w kształtowaniu idei narodu jako kategorii historycznej w myśli politycznej obozu narodowodemokratycznego, w: Marzyciele i realiści. O roli tradycji w polskiej myśli politycznej od upadku powstania styczniowego do XXI wieku, red. T. Sikorski, A. Wątor, Szczecin 2009.

Wojdyło W., Wychowanie jako kreatywny instrument budowy systemu wartości w myśli społeczno-politycznej obozu narodowego, w: Wychowanie a polityka. Cele polityczne jako czynnik determinujacy oddziaływanie wychowawcze, red. G. Radomski, K. Kalinowska, Toruń 2003.

Wolsza T., Narodowa Demokracja wobec chłopów w latach 1887-1914. Programy, polityka, dziatalność, Warszawa 1992.

Wójcik Z., Rozwój pojęcia inteligencja, Wrocław 1962.

Wrzesińska K., Kultura i cywilizacja w myśli Narodowej Demokracji (1893-1918). Między idea wychowania a polityka, Warszawa 2012.

Wrzesińska K., Naród jako duchowa wspólnota pokoleń: ku syntezie pozytywizmu i romantyzmu w myśli Narodowej Demokracji okresu zaborów, w: Rok 1863: narodziny nowej Polski, red. M. Rudaś-Grodzka et al., Warszawa 2016.

Zaleska I., Kościót, religia, duchowieństwo w świetle "Przegladu Wszechpolskiego" oraz "Przegladu Narodowego" w latach 1895-1914, „Historia i Polityka” 2007, 6. 


\section{NOTA O AUTORZE}

Aleksandra Lubczyńska - dr hab. w dziedzinie nauk humanistycznych w dyscyplinie bibliologia i informatologia, prof. UJK w Kielcach; bibliolog, prasoznawca, historyk. Zainteresowania naukowe: działalność wydawnicza i prasotwórcza Narodowej Demokracji do 1914 r.; działalność prasotwórcza i wydawnicza współczesnych środowisk narodowych (od 1989 r.); regionalizm w teorii i w praktyce. Autorka książek: Regionalizm kielecki w latach 1918-1939 (Kielce 2008); Michał Zborowski (1898-1995). Życie i działalność (Kielce 2008); Działalność wydawnicza Narodowej Demokracji w Galicji w dobie autonomii (1892-1914) (Pruszcz Gdański 2016); "Ateneum Polskie” 1908. "Przeglad Narodowy” 1908-1914. Adnotowana bibliografia zawartości (Kielce 2017). 